MINERALOGIA, 48, No 1-4: 3-22 (2017)

DE DE GRUYTER OPEN

DOI: $10.1515 / \mathrm{mipo}-2017-0008$

www.Mineralogia.pl

MINERALOGICAL SOCIETY OF POLAND

POLSKIE TOWARZYSTWO MINERALOGICZNE

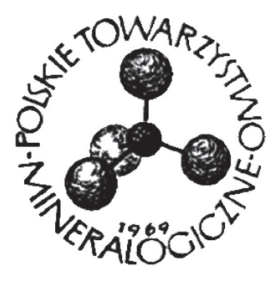

Original paper

\title{
Changes in the textural parameters of fly ash-derived Na-P1 zeolite during compaction processes
}

\author{
Rafał Panek $^{1 *}$, Magdalena Wdowin ${ }^{2}$, Lidia Bandura ${ }^{1}$, Ewa Wisła-Walsh ${ }^{3}$, \\ Paweł Gara ${ }^{3}$, Wojciech Franus ${ }^{1}$ \\ ${ }^{1}$ Department of Geotechnics, Civil Engineering and Architecture Faculty, Lublin University of Technology, \\ Nadbystrzycka 40, 20-618 Lublin, Poland; tel: +48815384378 \\ ${ }^{2}$ The Mineral and Energy Economy Research Institute of The Polish Academy of Sciences, Wybickiego 7, 31-261 \\ Kraków, Poland \\ ${ }^{3}$ AGH-University of Science and Technology, Kraków, Mickiewicza 30, 30-059, Poland \\ * Corresponding author \\ e-mail: r.panek@pollub.pl
}

Received: April 5, 2017

Received in revised form: July 25, 2017

Accepted: July 30, 2017

Available online: September 30, 2017

\begin{abstract}
This paper presents the possibility of receiving the granular forms of a zeolitic material of the Na-P1 type obtained from high-calcium fly ash in a semi-technical scale by means of three compacting techniques. The compaction process was carried out using cement, molasses and water glass as binders. Each of the proposed compacting methods affected the textural parameters of the obtained granular zeolite forms, as well as the binders used. In comparison to the other binders it was found that the cement binder had the smaller impact on the values of the textural parameters of the obtained compacted zeolite forms. The surface area for the zeolite Na-P1 was $98.49 \mathrm{~m}^{2} \cdot \mathrm{g}^{-1}$, for the cement as a binder was $69.23 \mathrm{~m}^{2} \cdot \mathrm{g}^{-1}$, for the molasses was $52.70 \mathrm{~m}^{2} \cdot \mathrm{g}^{-1}$ and for the water glass was $40.87 \mathrm{~m}^{2} \cdot \mathrm{g}^{-1}$. For this reason, the briquetting and extruding tests were carried out using cement as a binder.
\end{abstract}

Key-words: Na-P1, binders, tableting, briquetting, extrusion, textural parameters

\section{Introduction}

Fly ash is a by-product of coal combustion. Its storage in landfills or in wetlands is particularly troublesome for the environment, due to the necessary precautions to prevent 
the blowing out of silty fractions and insulating the soil before the migration of any kind of impurity from the fly ash (Mehra et al. 1998).

Currently, fly ash is used in the production of building materials (cement and concrete), the remediation of post-mining excavations or geotechnics. Among the various new fields of application for this type of waste, studies have been carried out on the possibility of their practical use in the production of geopolymers and zeolites (De la Varga et al. 2012; Franus et al. 2014; Matsi, Keramidas 1999; Mehra et al. 1998; Swanepoel, Strydom 2002; Sumer 2012; Yang et al. 2012).

Minerals such as zeolites are porous, hydrated, crystalline aluminosilicates of mainly alkali or alkaline earth elements, having a three-dimensional lattice composed of tetrahedrons $\left[\mathrm{AlO}_{4}\right]$ and $\left[\mathrm{SiO}_{4}\right]$ connected by their corners (Merrikhpour, Jalali 2012). Their structure is characterized by a regular construction of channels and chambers, which gives them a number of unique qualities including large sorption capacity, ion-exchange, molecular-sieve and catalytic properties. Due to their many useful properties, zeolites from fly ash are widely applied in environmental protection (Misaelides 2011; Perego et al. 2013; Vignola et al. 2011) for sludge and water purification from heavy metals and ammonium ions (Czurda, Haus 2002; Franus, Wdowin 2010; Merrikhpour, Jalali 2012; Zhang et al. 2011) or radionuclides (Chałupnik et al. 2013; Remenárová et al. 2014)._They also find application in the purification of flue gases from $\mathrm{SO}_{x}, \mathrm{CO}_{x}$ and volatile $\mathrm{Hg}$ removal (Morency et al. 2012; Wdowin et al. 2012; Wdowin et al. 2014; Wdowin et al. 2015), as well as in the removal of organic compounds from aqueous systems or industrial gases (Bandura et al. 2015; Bowman 2003; Kim, Ahn 2012; Northcott et al. 2010; Simpson, Bowman 2009; Szala et al. 2015).

However, regardless of the fly ash $\mathrm{F}$ class applied and the methodology of its conversion, synthesized zeolites are obtained in the form of fine, crystal powder material.

For this reason, it is necessary to compact them to suitable sizes or shapes in order to ensure proper mechanical strength and water resistance (Gara et al. 2008; Pietsch 2004).

The compaction of fine, powdery materials depends to a large extent on the physicochemical properties (moisture, particle size distribution and the shape of the grains) of the compacted material (Gara et al. 2008; Knight 2001; Lipkind 1987; Manikandan, Ramamurthy 2007; Srb, Ruzickova 1988).

Additionally, in order to obtain a granular form, most of the fine materials require the use of a suitable binder (Yoo, Jo 2003). In the case of the granulation of zeolite, clay minerals (mainly montmorillonite and kaolinite) are most commonly used as a binder (Charkhi 2012; Lipkind et al. 1987). However, such a process does not provide adequate mechanical strength or resistance to water for the granular zeolite forms (Ejsymont et al. 1975; Jagielska et al. 1988; Sochon, Salman 2010; Wajszel 1982). As a result, after completing the step of compaction with a binder, the obtained granulate is subjected to burning at a temperature ranging from $550^{\circ} \mathrm{C}$ to $600^{\circ} \mathrm{C}$, in order to give it the required mechanical properties and water resistance (Ejsymont, Witek 1986; Ejsymont et al. 1981; Ugal et al. 2008).

In the range of burning temperature, not all the zeolite materials are thermally stable. This includes Na-P1 zeolite among others, which is the most common industrially produced zeolite from fly ash (Franus 2012; Majchrzak-Kucęba 2011; Wdowin et al. 2014). Due to 
its poor thermal stability, it is necessary to search for other binders that would provide compacted forms of this zeolite with the slightly changed textural parameters, and the required other properties, without the need for a thermal treatment process (Atkins et al. 1995; Tharnzil 1997).

The aim of this paper was to obtain compacted forms of zeolite Na-P1 using the techniques of tableting, briquetting and extrusion, and the selection of the most suitable binder from the three applied (molasses, water glass and cement). Additionally, as there is no available data in the literature, the influence of storage time on the texture of the compacted forms of zeolite was also studied.

\section{Experimental}

\subsection{Materials}

The starting material for the preparation of compacted forms was a synthetic zeolite NaP1 type. The zeolite was prepared from fly ash with a high content of $\mathrm{CaO}$ through the process of hydrothermal reaction with the addition of sodium hydroxide. The fly ash used for synthesis came from the Rybnik power plant. The reaction conditions for the preparation of zeolite at pilot-scale were as follows: $20 \mathrm{~kg}$ of fly ash, $12 \mathrm{~kg}$ of $\mathrm{NaOH}, 90$ $\mathrm{dm}^{3}$ of water, temperature of $80^{\circ} \mathrm{C}$, and reaction time of $24 \mathrm{~h}$ (Franus 2012; Franus et al. 2014; Wdowin et al. 2014).

\subsection{Binder Study}

In the compaction process of Na-P1 zeolites, molasses, water glass, and blast furnace cement were used as binders. The molasses was obtained from the Ropczyce S.A. sugar factory, the water glass from the Rudniki S.A. chemical plant, and the blast furnace cement (CEM III/A32.5N) from the Ożarów cement plant.

\subsection{Compaction study}

The compaction process was carried out according to the scheme shown in Figure 1. At the first stage, the tableting technique was used due to the fact that this method is the easiest, most commonly used, and requires little material for compaction. The binders were added in the amount of $10 \%$ by weight, relating to the weight of the zeolite under compaction. Approximately 7-8 g of the zeolite material with a moisture content of $22 \%$ was mixed with the selected types of binders. In order to obtain a mixture susceptible to compaction in the stamp press, the tested material was humidified to a moisture content of $30 \%$ for all the binders used.

\subsection{Seasoning study}

The tableting process was carried out in a ZDM-1 stamp press with a closed cylindrical die with an inner diameter of $20 \mathrm{~mm}$, using the following conditions: pressure stamp of press - $40 \mathrm{MPa}$, time of tableting $-5 \mathrm{sec}$. The obtained tablets were tested after $48 \mathrm{~h}$ of 
seasoning under air-dry conditions and after $72 \mathrm{~h}$ seasoning in water. After choosing the best binder (in this case cement), a briquetting and an extrusion of Na-P1 zeolite was carried out. Then, the textural properties were determined after a period of $48 \mathrm{~h}$ and 360 days of seasoning of the compacted forms under air-dry conditions. In addition, for the tableting process with cement binder, studies in the dry-air condition after a period of 360 days were also conducted.

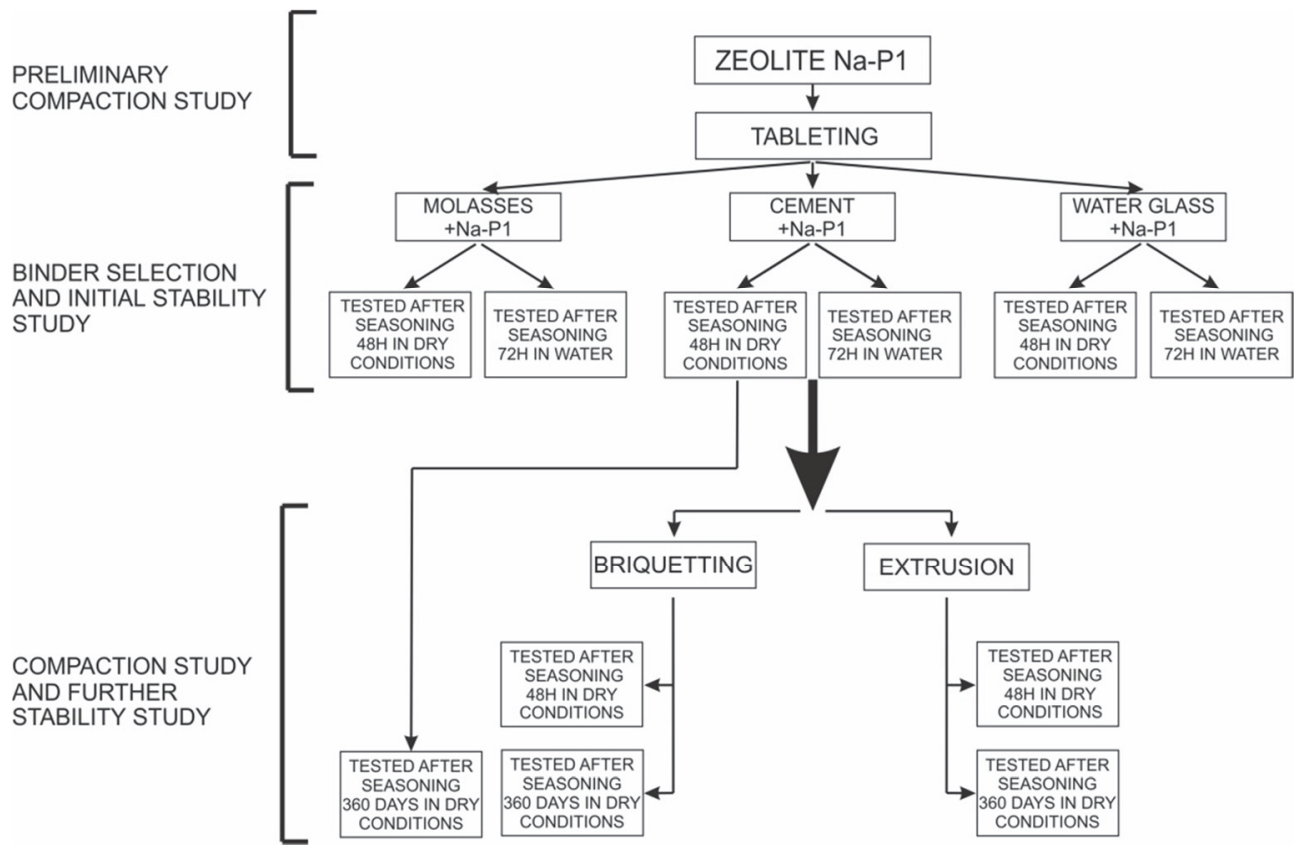

Fig. 1. Schematic diagram of the compaction processes

Briquetting was performed using an LPW 450 laboratory roller press equipped with saddle-shaped rings. Sample preparation consisted of the addition of $10 \%$ cement in relation to its weight, mixing and adding a quantity of water. The material subjected to the compaction process had a humidity in the range of $30.3-31.8 \%$.

During the first $2 \mathrm{~h}$ of the seasoning process, the resulting material was humidified by spraying with water several times, aiming to obtain humidity similar to that in the compaction process in the press stamp (tableting). After an established period of time, the compacts (as in the case of tableting) were subjected to crushing in the disintegration process.

Extrusion (pressing) was performed in the piston provided with the outlet having a diameter of $5 \mathrm{~mm}$. The material for the extrusion experiment was taken from the mixture prepared for briquetting. The resulting compacts were seasoned and mechanically crushed analogically to the case of the briquetted samples.

The abbreviations of zeolite Na-P1 samples obtained through all the tested processes are presented in Table 1. 
Abbreviations of tested samples in the compaction processes

\begin{tabular}{|c|c|}
\hline Symbols & Compaction process \\
\hline Na-P1 & No compaction \\
\hline Na-P1-M & Tableting with molasses (time of seasoning $48 \mathrm{~h}$ dry conditions) \\
\hline Na-P1-S & Tableting with water glass (time of seasoning $48 \mathrm{~h}$ dry conditions) \\
\hline Na-P1-C & Tableting with cement (time of seasoning $48 \mathrm{~h}$ dry conditions) \\
\hline Na-P1-E & Extrusion with cement (time of seasoning $48 \mathrm{~h}$ dry conditions) \\
\hline Na-P1-B & Briquetting with cement (time of seasoning $48 \mathrm{~h}$ dry conditions) \\
\hline $\mathrm{Na}-\mathrm{P} 1-\mathrm{M} 72 \mathrm{~h} \mathrm{H}_{2} \mathrm{O}$ & Tableting with molasses (time of seasoning $72 \mathrm{~h}$ in water) \\
\hline $\mathrm{Na}-\mathrm{P} 1-\mathrm{S} 72 \mathrm{~h} \mathrm{H} \mathrm{H}_{2} \mathrm{O}$ & Tableting with water glass (time of seasoning $72 \mathrm{~h}$ in water) \\
\hline $\mathrm{Na}-\mathrm{P} 1-\mathrm{C} 72 \mathrm{~h} \mathrm{H}_{2} \mathrm{O}$ & Tableting with cement (time of seasoning $72 \mathrm{~h}$ in water) \\
\hline Na-P1-C 360 & Tableting with cement (time of seasoning 360 days dry conditions) \\
\hline Na-P1-E 360 & Extrusion with cement (time of seasoning 360 days dry conditions) \\
\hline Na-P1-B 360 & Briquetting with cement (time of seasoning 360 days dry conditions) \\
\hline
\end{tabular}

\subsection{Characterization methods}

The mineral composition of all compacted forms as well as the parent zeolite material was determined by X-ray diffraction (XRD) using X'pert (Panalytical) with a PW 3050/60 goniometer, $\mathrm{CuK} \alpha$ radiation, and a graphite monochromator. The analysis was carried out within the angle range of $5^{\circ}-65^{\circ}$ ( 2 Theta). Panalytical X'Pert Highscore software (High Score Plus v. 4.1) was used in order to process the diffraction data. The identification of mineral phases in the zeolite was based on the PDF-2 Release 2010 database formalized by the ICDD.

The morphological forms, microstructure, and the chemical composition of the tested zeolites were determined by means of a scanning electron microscope (SEM) FEI Quanta 250 FEG (FEI, Hilsboro, OR, USA), equipped with a system of chemical composition analysis, based on energy dispersive spectrometry (EDS) X-ray-EDS from the EDAX company (EDAX Inc., Mahwah, NJ, USA).

The thermal analysis (DTA/TG) was performed on a Jupiter STA 449 F3 Netzsch coupled with a quadrupole mass spectrometer Aeolos QMS 403C in an air atmosphere at a temperature range of $25^{\circ} \mathrm{C}-1000^{\circ} \mathrm{C}$ with the heating rate raised at $10^{\circ} \mathrm{C}$ per minute.

The elemental composition of the investigated Na-P1 zeolite was determined by energy dispersive X-ray fluorescence by means of a spectrometer Epsilon 3 Panalytical. The tests were carried out at range of Na-Am on apparatus equipped with a lamp with a $9 \mathrm{~W} \mathrm{Rh}$, $50 \mathrm{kV}, 1 \mathrm{~mA}$ anode.

Measurements of the particle size of the zeolite material and cement used as the binder were carried out by laser diffraction method on a Malvern Mastersizer 2000 apparatus. The measurements were performed in distilled water having a refractive index of 1.33 as 
a dispersion liquid. The samples were treated with ultrasound at approximately the maximum power, for a total of $4 \mathrm{~min}$. The ultrasound was derived from an ultrasound probe having a maximum power of $300 \mathrm{~W}$. For the calculation of the particle size, the Mie theory was adopted (Bieganowski et al. 2012).

For the liquid binders (molasses and water glass), the viscosity and density were determined using a Hoppler viscometer.

The textural parameters (specific surface area, surface area, volume of micropore and mesopores, and pore distribution) were determined based on the progression of lowtemperature adsorption/desorption isotherm of the nitrogen vapor at a temperature of $194.85^{\circ} \mathrm{C}$. The sample before the test had been degassed under a controlled temperature $\left(200^{\circ} \mathrm{C}\right.$ for a period of $12 \mathrm{~h}$ ) and the pressure had been reduced to $0.2 \mathrm{~Pa}$. To calculate the specific surface area, the BET theory was used. The volume and surface parameters of the micropores and mesopores were determined with the "t" method (Lippens, de Boer 1965; Lippens et al. 1964). For the textural studies, an ASAP 2020 apparatus from Micromeritics was used.

\section{Results and discussion}

\subsection{Characteristics of raw Na-P1 material and binders}

The major zeolite phase in the process of compaction was zeolite Na-P1, obtained in rectangle/parallelogram rosette-like forms, as seen in Figure 2. The particle size distribution and its statistical parameters of zeolite material are shown in Figure 4 and Table 3. The presence of a zeolite phase type Na-P1 was recognized as the characteristic reflections $\mathrm{d}_{\mathrm{hkl}}$ $=7.10 \AA, 5.01 \AA, 4.10 \AA$, and $3.18 \AA$. The quantitative zeolite content calculated from the XRD was $75 \mathrm{wt} \%$.
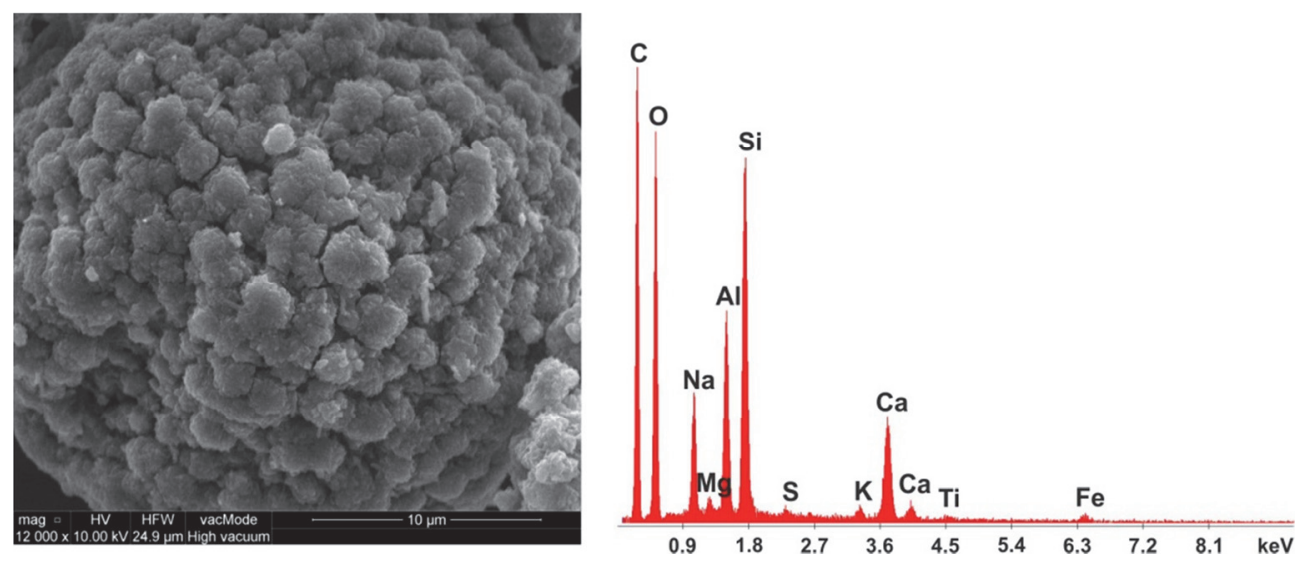

Fig. 2. SEM microphotograph of zeolite Na-P1 and spectrum of chemical composition (EDS) 


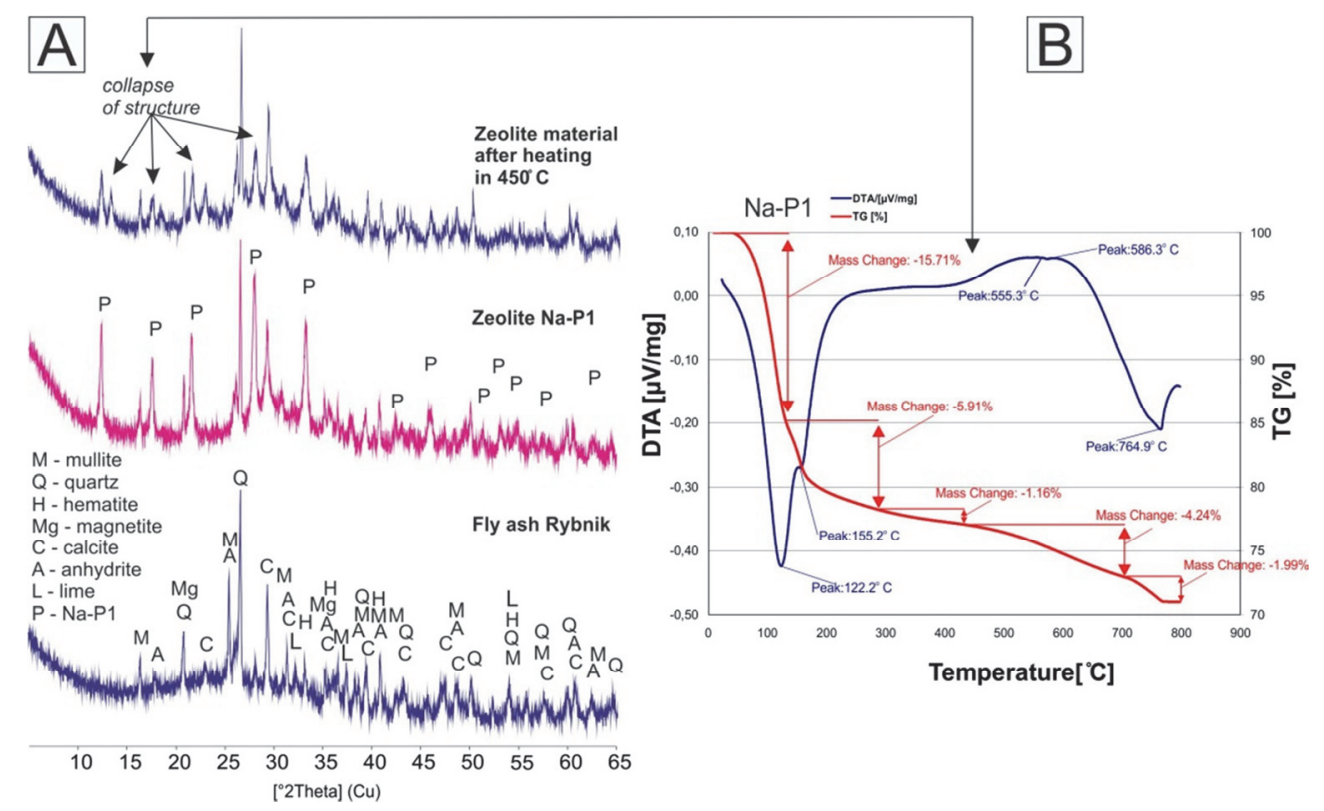

Fig. 3 Phase composition of fly ash from Rybnik power plant. (a) Na-P1 zeolite material and the material formed after calcination at $450^{\circ} \mathrm{C}$; (b) TG/DTG/DTA curves of Na-P1 zeolite

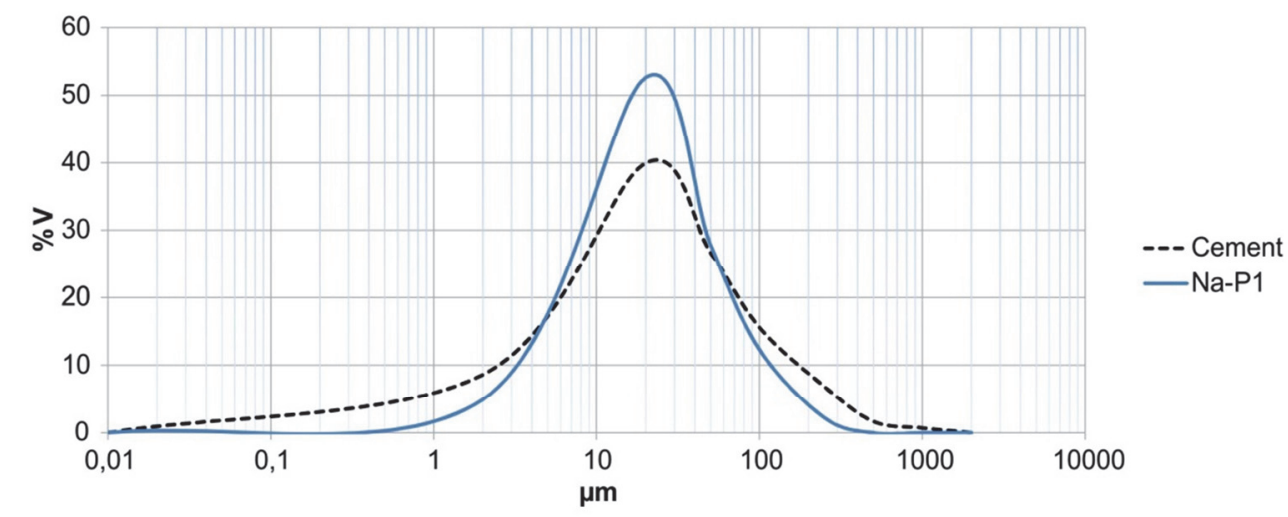

Fig. 4. Particle size distribution curves of Na-P1 zeolite and cement used as a binder in the compaction process

Thermal analysis (DTA/TG) and X-ray phase analysis after thermal treatment showed that the tested zeolite was thermally unstable (Fig. 3). At a temperature above $450^{\circ} \mathrm{C}$, collapsing of the structure took place, as well as silica recrystallization.

The chemical composition of the obtained zeolite material was as follows (in wt $\%$ ): $\mathrm{SiO}_{2}$ 38.55; $\mathrm{Al}_{2} \mathrm{O}_{3}$ 14.59; $\mathrm{Fe}_{2} \mathrm{O}_{3}$ 5.26; $\mathrm{MgO}$ 1.307; $\mathrm{CaO}$ 14.15; $\mathrm{K}_{2} \mathrm{O}$ 0.93; $\mathrm{Na}_{2} \mathrm{O}$ 8.78; $\mathrm{SO}_{3}$ 0.065; LOI 24.7. The dominant components of the zeolite phase were $\mathrm{SiO}_{2}$ and $\mathrm{Al}_{2} \mathrm{O}_{3}$ (at 
a ratio of approx. 2.64), accompanied by a significant amount of $\mathrm{CaO}$, as confirmed by the EDS spectrum (Fig. 2). The different $\mathrm{Si} / \mathrm{Al}$ ratio in the zeolites determines their properties. Low silica zeolites are characterized by increased acid resistance and stability at higher temperatures and hydrophilicity. On the other hand, high silica zeolites are characterized by a high degree of ion exchange.

TABLE 2

Physicochemical parameters of molasses and water glass

\begin{tabular}{lll}
\hline Parameter & Molasses & Water Glass \\
\hline dynamic viscosity $\eta^{20}[\mathrm{cP}]$ & 10015 & 249.909 \\
kinematic viscosity $\eta^{20} / \mathrm{d}^{20}[\mathrm{cSt}]$ & 7321.585 & 167.257 \\
density $\left[\mathrm{g} / \mathrm{cm}^{3}\right]$ & 1.3679 & 1.4942 \\
\hline
\end{tabular}

TABLE 3

Grain size distribution for cement and Na-P1 zeolite - statistical parameters

\begin{tabular}{lll}
\hline Parameter & Na-P1 & Cement \\
\hline Median $-\mathrm{D} 50[\mu \mathrm{m}]$ & 14.238 & 18.281 \\
Mode $[\mu \mathrm{m}]$ & 24.144 & 25.512 \\
D10 $[\mu \mathrm{m}]$ & 3.134 & 3.781 \\
D90 $[\mu \mathrm{m}]$ & 60.016 & 58.323 \\
SCUM $\left[\mathrm{m}^{2} \cdot \mathrm{g}^{-1}\right]$ & 0.839 & 0.75 \\
\hline
\end{tabular}

Table 2 shows the physical and chemical parameters of the liquid binders used, which vary significantly from each other.

Figure 4 and Table 3 show respectively the particle size distribution and its statistical parameters for a solid binder and the Na-P1 zeolite. They clearly show that both materials are very similar to each other in terms of particle size and distribution, which is an important factor in the compaction process. Similar particle size distribution of the "blends" under compaction increased the packing density by minimizing the void space between grains, and decreased the binder amount added. This reduced the energy and time needed to dry the obtained contacts.

\subsection{Preliminary compaction study (tableting)}

\subsubsection{Binder selection}

Compacted materials in the form of tablets and their mineral composition are shown in Figure 5. The XRD analysis of the phase composition of the tablets directly after the compaction and seasoning for $48 \mathrm{~h}$ in the air-dry state and after $72 \mathrm{~h}$ seasoning in the water 
showed that in the case of the addition of the liquid binders (molasses and water glass), there was no change in the phase composition. In turn, minor changes in mineral composition were observed for the tablets obtained with the cement. An increase of calcite content and amorphous phase was noted. Such changes are the result of the hydration processes of the clinker phases of cement (Kurdowski 2010; Scrivener, Nonat 2011).
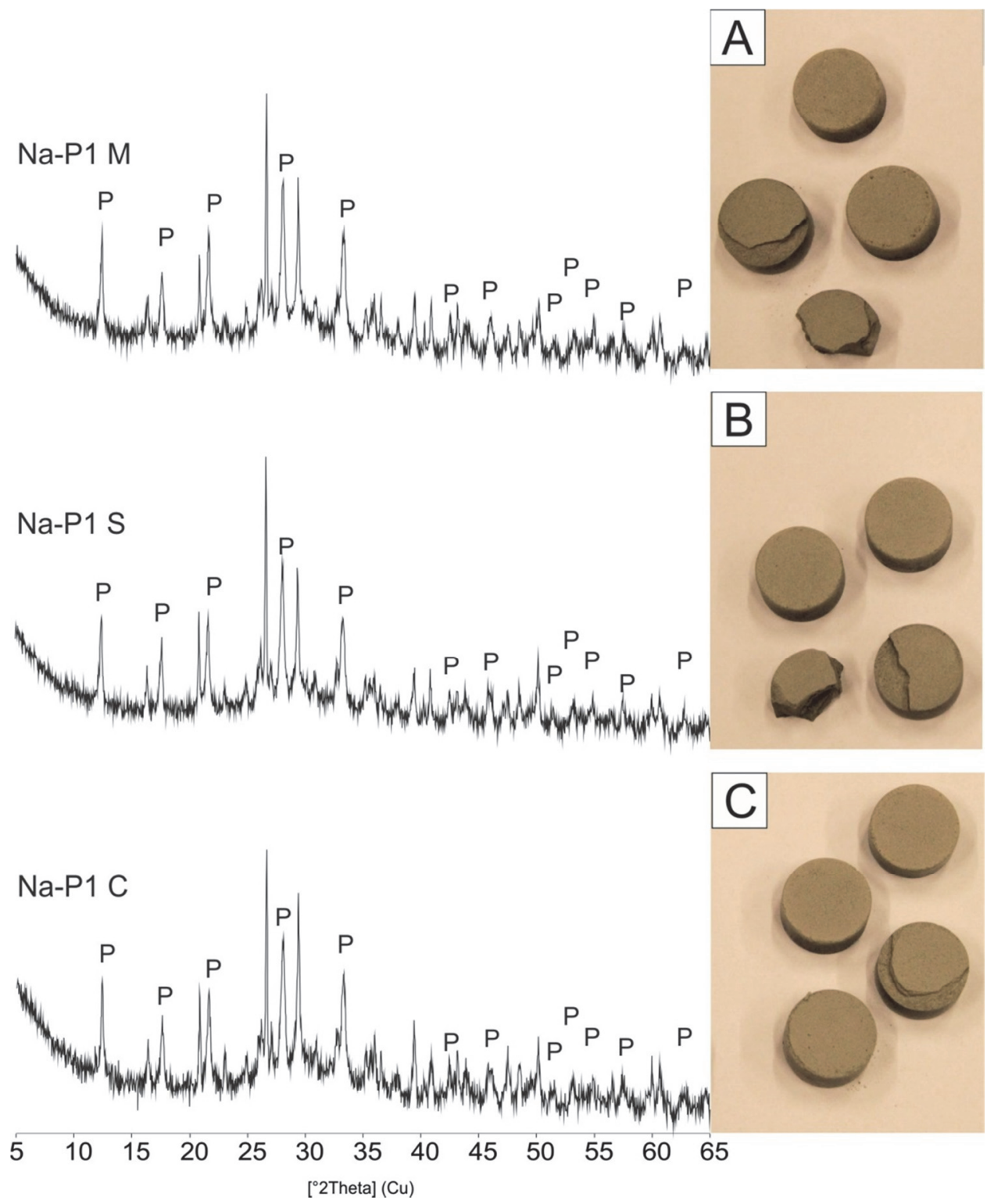

Fig. 5. Bonded zeolite samples: molasses (a), water glass (b), cement (c), and their mineral composition 
The textural studies showed that regardless of the nature of the binder, their addition caused a decrease in the specific surface area $\left(\mathrm{S}_{\mathrm{BET}}\right)$, the surface of the mesopores $\left(\mathrm{S}_{\text {mes. }}\right)$ and the micropores $\left(\mathrm{S}_{\text {mic.t }}\right)$ in the tableted form of zeolites. The smallest changes in these parameters, compared to the starting zeolite, were in the case of using cement as a binder (decrease of approx. 30\%; Table 4). In the case of the micropore surface, the differences in the decrease of these values were similar, regardless of the type of binder used. The lowest decrease in micropore surface area was recorded for water glass. The highest influence on the surface of the mesopores was observed for the molasses and water glass binders, which reduced this value by $48 \%$ and $65 \%$, respectively.

TABLE 4

The textural parameters for Na-P1 zeolite and their tableting forms using various binders

\begin{tabular}{lllll}
\hline Parameter & Na-P1 & Na-P1 C & Na-P1 M & Na-P1 S \\
\hline $\mathrm{S}_{\text {BET }}\left[\mathrm{m}^{2} \cdot \mathrm{g}^{-1}\right]$ & 98.493 & 68.231 & 52.701 & 40.871 \\
$\mathrm{~S}_{\text {mic. } .[}\left[\mathrm{m}^{2} \cdot \mathrm{g}^{-1}\right]$ & 17.694 & 11.904 & 10.873 & 14.142 \\
$\mathrm{~S}_{\text {mes. } .}\left[\mathrm{m}^{2} \cdot \mathrm{g}^{-1}\right]$ & 88.382 & 62.051 & 45.960 & 30.470 \\
$\mathrm{~V}_{\text {mic.t }}\left[\mathrm{cm}^{3} \cdot \mathrm{g}^{-1}\right]$ & 0.006 & 0.004 & 0.004 & 0.005 \\
$\mathrm{~V}_{\text {mes.t. }}\left[\mathrm{cm}^{3} \cdot \mathrm{g}^{-1}\right]$ & 0.2957 & 0.2085 & 0.1970 & 0.189 \\
$\mathrm{~V}_{\text {tot }}\left[\mathrm{cm}^{3} \cdot \mathrm{g}^{-1}\right]$ & 0.302 & 0.212 & 0.201 & 0.194 \\
$\mathrm{D}_{\text {mes }}[\mathrm{nm}]$ & 13.381 & 13.210 & 17.144 & 24.739 \\
$\mathrm{D}_{\text {med }}[\mathrm{nm}]$ & 11.382 & 11.490 & 14.144 & 17.007 \\
\hline
\end{tabular}

The changes in the surface area values were accompanied by changes in the volume of the pore size. The total pore volume decrease from $30 \%$ to $38 \%$, with a similar decrease observed in the case of the meso- and micropores volume (form $16 \%$ to $33 \%$ for micropores volume $\mathrm{V}_{\text {mic.t }}$, and from $29 \%$ to $36 \%$ for mesopores volume $\mathrm{V}_{\text {mes.t. }}$ ).

As a consequence of the changes in the values of the surface and volume parameters, there were changes observed in the calculations of their basis values: the average mesopore diameter and total pore volume. Mainly, the smallest changes were observed in the case of cement (approximately 1\% for both the average diameter of the mesopores and total pore volume). In the case of the molasses and water glass, the average mesopore diameters increased by $28 \%$ and $84 \%$, while the average diameters of the total pore volumes increased by $25 \%$ and $50 \%$, respectively. This may be related to the density of glass and molasses (Table 2) that were added as a liquid binder.

The adsorption/desorption isotherms of nitrogen vapor for all tested materials are shown in Figure 6. 


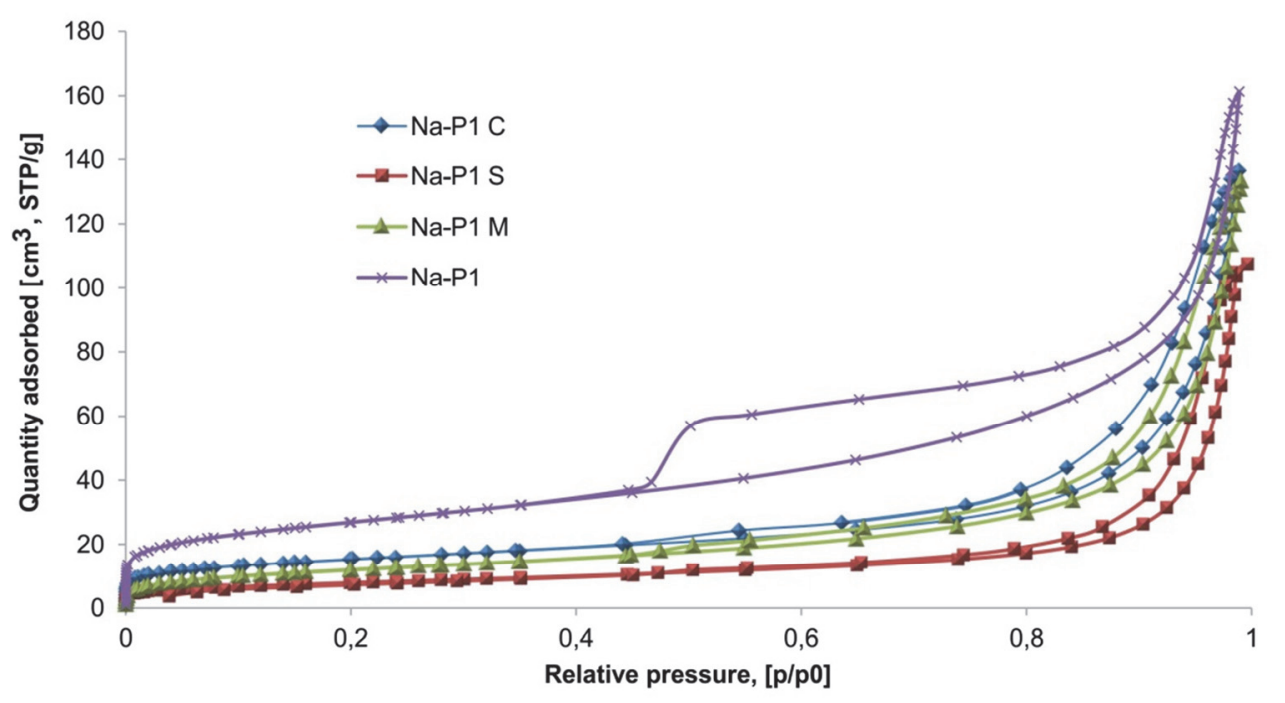

Fig. 6. Adsorption/desorption isotherms of nitrogen for Na-P1 zeolite and their bonded forms

The adsorption isotherms represent a type II (according to IUPAC), but the hysteresis loops have a different size and shape. The nitrogen sorption isotherm for zeolite Na-P1 has a higher position relating to the isotherm for the compacted materials. This is due to a decrease in the specific surface area parameters. For zeolite Na-P1, the hysteresis loop corresponds to the type of $\mathrm{H} 2 / \mathrm{H} 3$. This may indicate the presence of mesopores between the agglomerated zeolite particles about irregular, close-to-spherical shapes (Sarbak 2002). Compacted materials are characterized by narrower hysteresis loops, which can be attributed to the $\mathrm{H} 3$ type of hysteresis. Such a loop is characteristic for materials with plate crystal structure and accompanied by the formation of slit pores (Klinik 2000). Probably, the course and shape of the hysteresis may be the result of the reordering of the grains of the bonded material due to the applied pressure during the tableting process.

The smallest changes in the texture parameters of the tested zeolite samples were observed in the case of the application of the cement binder, which can be explained by the fact that cement was added in a fine form, of which the statistical parameters, determined from the particle size distribution, are similar to the corresponding parameters of the particle size distribution for the Na-P1 zeolite (Fig. 4; Table 3).

As the two remaining binders were added to the compacted zeolite in liquid form, it is most likely that by surrounding the grains of compacted zeolite the solutions of binder created a different number of pores of different diameters between them, as well as being caused meso- and micropore blockages in the zeolite grains, which explains the observed changes in the textural parameters (Table 4).

\subsubsection{Initial stability study}

The bond strength of the cement in time is dependent upon the amount of added water (ratio $\mathrm{H}_{2} \mathrm{O} /$ concrete), which causes phase changes that affect the textural parameters of the 
bonded form (Singh et al. 2002). In the case of the other two binders, on the other hand, variable amounts of water may cause diffusion of the liquid binder to the grain structure of the zeolite. For this reason, additional tests were performed for the tablet samples seasoned for $72 \mathrm{~h}$ in water.

Analysis of the mineral composition diffraction curves of each zeolite with the addition of the three tested binders (Fig. 7) showed that seasoning in water did not affect the phase composition of them in comparison to the tablets seasoned under air-dry conditions.

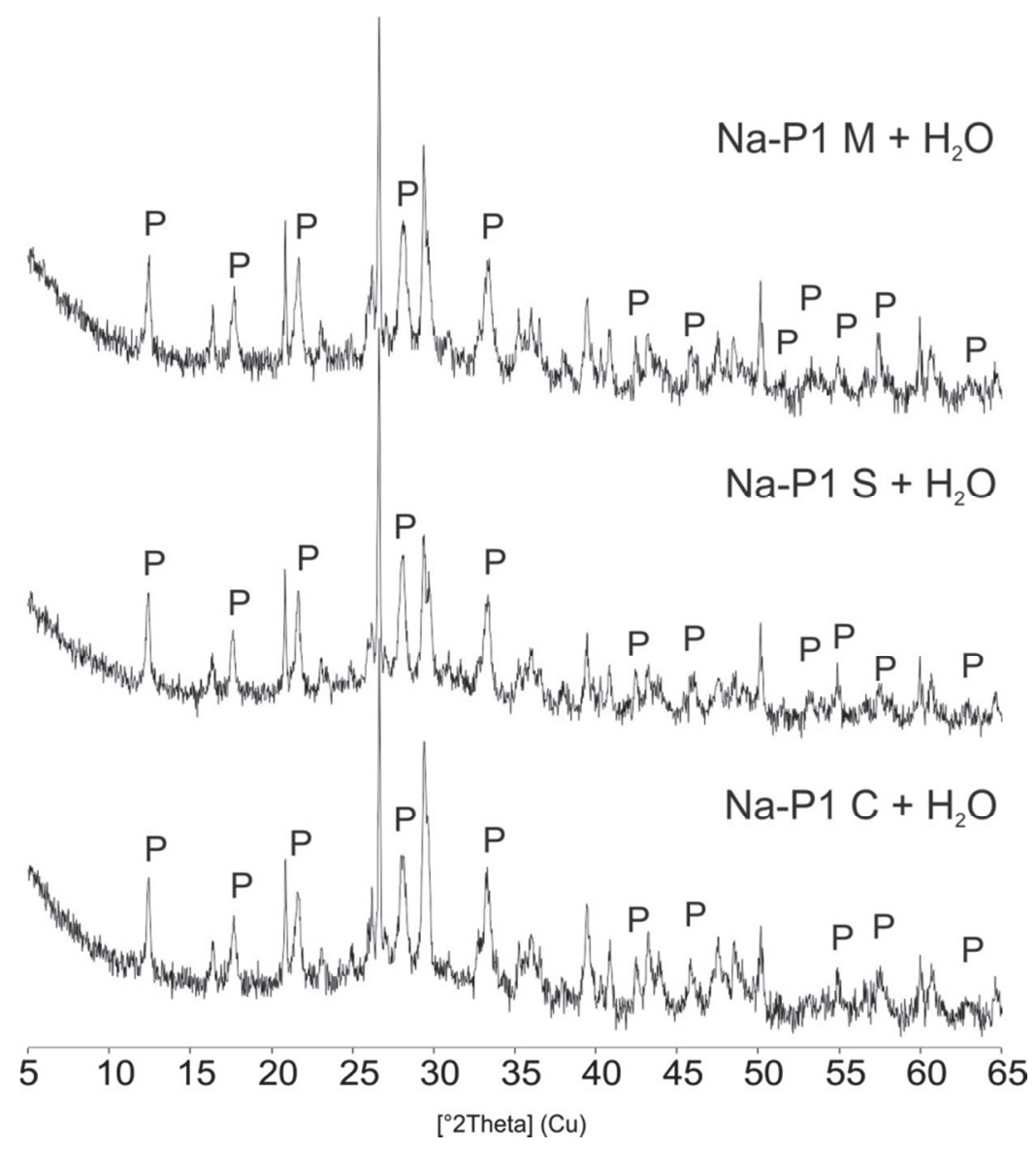

Fig. 7. The XRD diffraction patterns of the mineral composition of the zeolite compacted with cement, water glass and molasses after $72 \mathrm{~h}$ seasoning in water

In turn, from analyzing the textural parameters of the tablets seasoned for $72 \mathrm{~h}$ (Table 5) it can be concluded that the seasoning in water for $72 \mathrm{~h}$, compared to the seasoned forms in air-dry conditions, increased the specific surface area $\left(\mathrm{S}_{\mathrm{BET}}\right)$, and the surface of the micropores $\left(\mathrm{S}_{\text {mic.t. }}\right)$ and mesopores $\left(\mathrm{S}_{\text {mes.t. }}\right)$. In relation to the forms unseasoned in water, the increase of the total surface area was the smallest for the sample compacted with cement (approximately 26\%), while in the case of the two other binders it was 1.5 times greater than that of the cement. The micropores' surface area for all the tested binders increased by 
an average of $60 \%$, and the highest increase was observed for the cement binder. An increase in the mesopore surface area was also observed, which was the smallest for the cement (approximately 10\%), while for the remaining binders this was approximately $40 \%$. Accordingly, the micropore volume $\left(\mathrm{V}_{\text {mic.t }}\right)$ increased by approximately $50 \%$ for the molasses and water glass, and by $66 \%$ for the cement. The mesopore volume $\left(\mathrm{V}_{\text {mes.t }}\right)$ and total pore volume $\left(\mathrm{V}_{\text {tot }}\right)$ increase was insignificant in the case of the cement (at a few percentages), while in the case of the other binders this was approximately $16 \%$.

TABLE 5

Compacted zeolite materials after seasoning in $\mathrm{H}_{2} \mathrm{O}$ for $72 \mathrm{~h}$

\begin{tabular}{llll}
\hline Parameter & $\mathrm{Na}-\mathrm{P} 1-\mathrm{C} 72 \mathrm{~h} \mathrm{H} \mathrm{H}_{2} \mathrm{O}$ & $\mathrm{Na}-\mathrm{P} 1-\mathrm{M} 72 \mathrm{~h} \mathrm{H} \mathrm{H}_{2} \mathrm{O}$ & Na-P1-S 72h H $\mathrm{H}_{2} \mathrm{O}$ \\
\hline $\mathrm{S}_{\mathrm{BET}}\left[\mathrm{m}^{2} \cdot \mathrm{g}^{-1}\right]$ & 93.221 & 94.630 & 80.023 \\
$\mathrm{~S}_{\text {mic.t }}\left[\mathrm{m}^{2} \cdot \mathrm{g}^{-1}\right]$ & 35.670 & 25.792 & 30.964 \\
$\mathrm{~S}_{\text {mes. } .}\left[\mathrm{m}^{2} \cdot \mathrm{g}^{-1}\right]$ & 68.401 & 77.402 & 58.290 \\
$\mathrm{~V}_{\text {mic.t }}\left[\mathrm{cm}^{3} \cdot \mathrm{g}^{-1}\right]$ & 0.013 & 0.010 & 0.011 \\
$\mathrm{~V}_{\text {mes.t }}\left[\mathrm{cm}^{3} \cdot \mathrm{g}^{-1}\right]$ & 0.211 & 0.232 & 0.215 \\
$\mathrm{~V}_{\text {tot }}\left[\mathrm{cm}^{3} \cdot \mathrm{g}^{-1}\right]$ & 0.224 & 0.241 & 0.226 \\
$\mathrm{D}_{\text {mes }}[\mathrm{nm}]$ & 12.360 & 11.981 & 14.720 \\
$\mathrm{D}_{\text {med }}[\mathrm{nm}]$ & 8.610 & 9.349 & 10.108 \\
\hline
\end{tabular}

Consequently, the average diameter of the mesopores $\left(\mathrm{D}_{\text {mes }}\right)$ decreased, with the lowest in the case of cement by $7 \%$, while the highest was for the other two cases by $43 \%$ for the molasses and $68 \%$ for the water glass. The average pore diameter decreased by $33 \%$ for cement, molasses by $51 \%$, and water glass by $68 \%$.
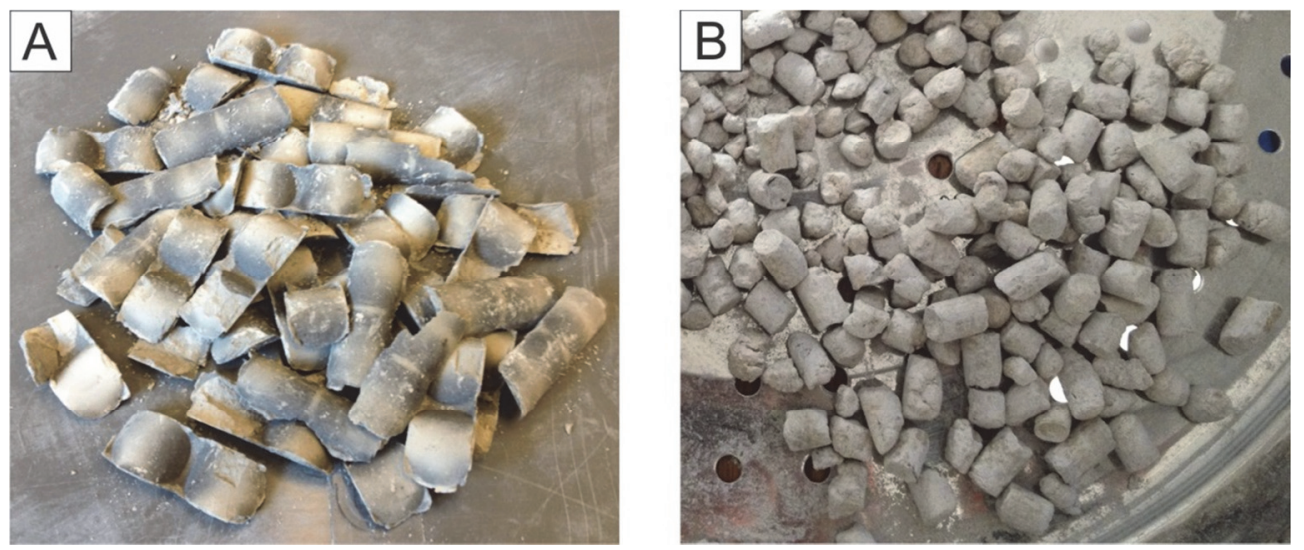

Fig. 8. Zeolite material after the process: (a) briquetting, (b) extrusion 


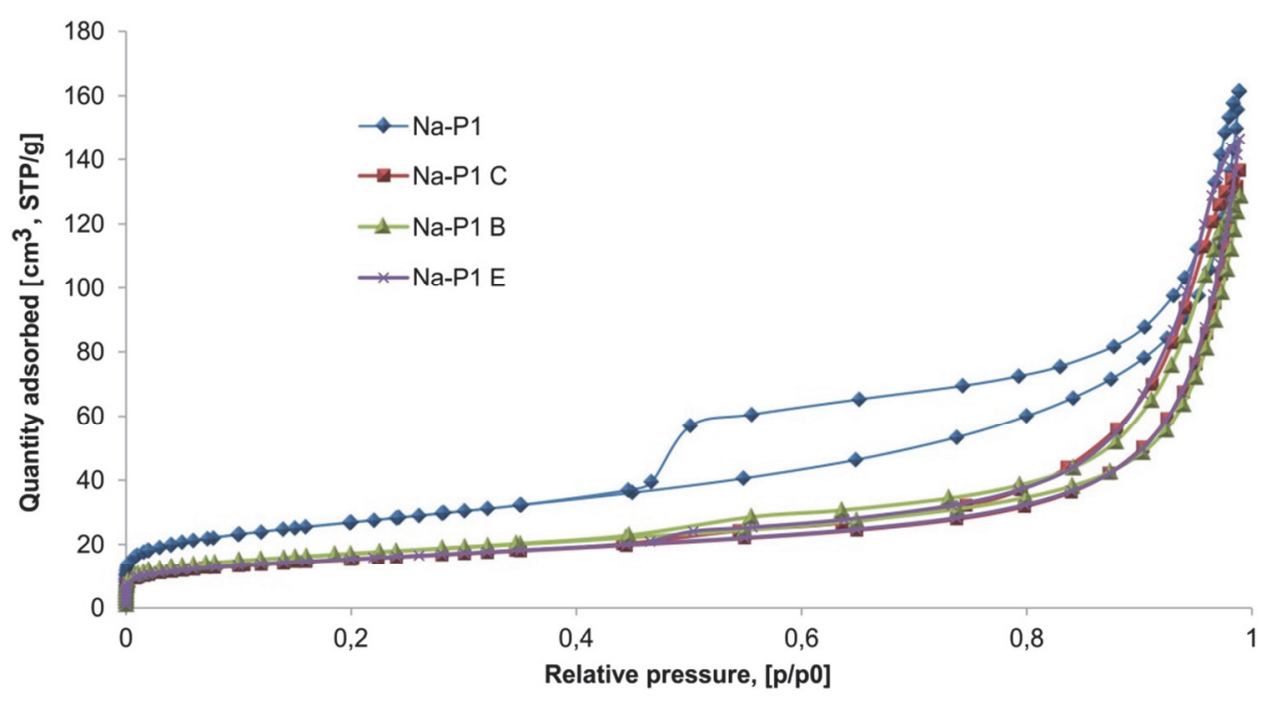

Fig. 9. The adsorption/desorption isotherms for the starting Na-P1 zeolite and the three tested compacts with cement

In conclusion, the seasoning of the tablets in water for a period of $72 \mathrm{~h}$ resulted in changes in the textural parameters, but did not change the phase composition (Fig. 9). It can be assumed that in the case of molasses and water glass, such a phenomenon is caused by the improved dissolving of binders, exposing the porosity of the zeolite material. We can also suspect the formation of secondary phases in the cement, but their insignificant content and the degree of crystallinity did not allow their identification using the adopted methods.

Furthermore, while for cement the $72 \mathrm{~h}$ seasoning in water increased the strength of the tablets, in the case of water glass and molasses the reverse trend was observed.

These observations were confirmed by testing the mechanical strength and thermal resistance. The mechanical strength was evaluated by dropping (Pietsch 2004), whereas thermal resistance was evaluated by burning the sample for $3 \mathrm{~h}$ in a muffle furnace at $250^{\circ} \mathrm{C}$, which is below the temperature of the collapse structure of zeolite. For each of the tests undertaken, the zeolite bonded by molasses and water glass disintegrated. Therefore, for further tests (briquetting and extrusion processes) cement was selected as the binder.

\subsection{Compaction study (briquetting and extrusion processes)}

Obtained from the briquetting and extrusion processes, the compacts were subjected to the seasoning process for $48 \mathrm{~h}$ in an air-dry state (Fig. 8a, b) and textural tests.

The nitrogen adsorption/desorption isotherms for samples after the briquetting (B), extrusion (E) and tableting (C) processes are shown in Figure 9, while the textual parameters are collected in Table 6. The nitrogen sorption isotherm for Na-P1 zeolite is located above the isotherm of zeolite compacted by all the techniques used. All the measured isotherms for the samples compacted with cement are of the type II (according to IUPAC), while the accompanying hysteresis loops are of the $\mathrm{H} 2 / \mathrm{H} 3$ type, which indicates 
the presence of mesopores between the agglomerated zeolite particles of irregular shapes similar to spheres, regardless of the compacting method.

As can be seen from the data in Table 6, all compacts receiving the three tested compaction methods (i.e. briquetting, extrusion and tableting with the same percentage of cement) exhibit integrated forms (Fig. 9) with different textures (Table 6). This is a result of differences in the applied pressure during compaction by those three methods and the amount of added water, which is also related to the technique used. This data correlates well with the data in Table 5, where after seasoning in water, the value of the specific surface area for the tablets compacted with cement is approximately $100 \mathrm{~m}^{2} \mathrm{~g}^{-1}$. This applies in particular to the briquetting, as the briquettes were seasoned for $48 \mathrm{~h}$, and supports the previously presented idea of creating a secondary texture by the reaction of the cement components with the fly ash residues.

TABLE 6

Textural parameters of Na-P1 zeolite compacted by the three tested techniques after $48 \mathrm{~h}$

\begin{tabular}{llll}
\hline Parameter & Na-P1 48C & Na-P1 48B & Na-P1 48E \\
\hline $\mathrm{S}_{\mathrm{BET}}\left[\mathrm{m}^{2} \cdot \mathrm{g}^{-1}\right]$ & 68.232 & 100.073 & 52.690 \\
$\mathrm{~S}_{\text {mic. } t}\left[\mathrm{~m}^{2} \cdot \mathrm{g}^{-1}\right]$ & 11.903 & 31.826 & 15.941 \\
$\mathrm{~S}_{\text {mes.t }}\left[\mathrm{m}^{2} \cdot \mathrm{g}^{-1}\right]$ & 62.050 & 78.698 & 41.421 \\
$\mathrm{~V}_{\text {mic. } .}\left[\mathrm{cm}^{3} \cdot \mathrm{g}^{-1}\right]$ & 0.004 & 0.011 & 0.005 \\
$\mathrm{~V}_{\text {mes.t }}\left[\mathrm{cm}^{3} \cdot \mathrm{g}^{-1}\right]$ & 0.209 & 0.230 & 0.221 \\
$\mathrm{~V}_{\text {tot }}\left[\mathrm{cm}^{3} \cdot \mathrm{g}^{-1}\right]$ & 0.2125 & 0.241 & 0.227 \\
$\mathrm{D}_{\text {mes }}[\mathrm{nm}]$ & 13.213 & 11.679 & 21.341 \\
$\mathrm{D}_{\text {med }}[\mathrm{nm}]$ & 11.492 & 8.723 & 15.970 \\
\hline
\end{tabular}

\subsubsection{Further stability study of bonded materials}

Due to the high content of $\mathrm{CaO}$ in the fly ash from the Rybnik power plant, this ash changes its phase composition and properties over time (Wisła-Walsh 1999). Therefore, to check the stability of the texture of the Rybnik fly ash-derived Na-P1 zeolite compacted forms obtained by the tableting, briquetting and extrusion methods, nitrogen sorption isotherms were measured after one year.

In Figure 10, adsorption/desorption isotherms measured after one year and obtained by the materials compacted by the three tested methods are shown, while the textural parameters are presented in Table 7. 


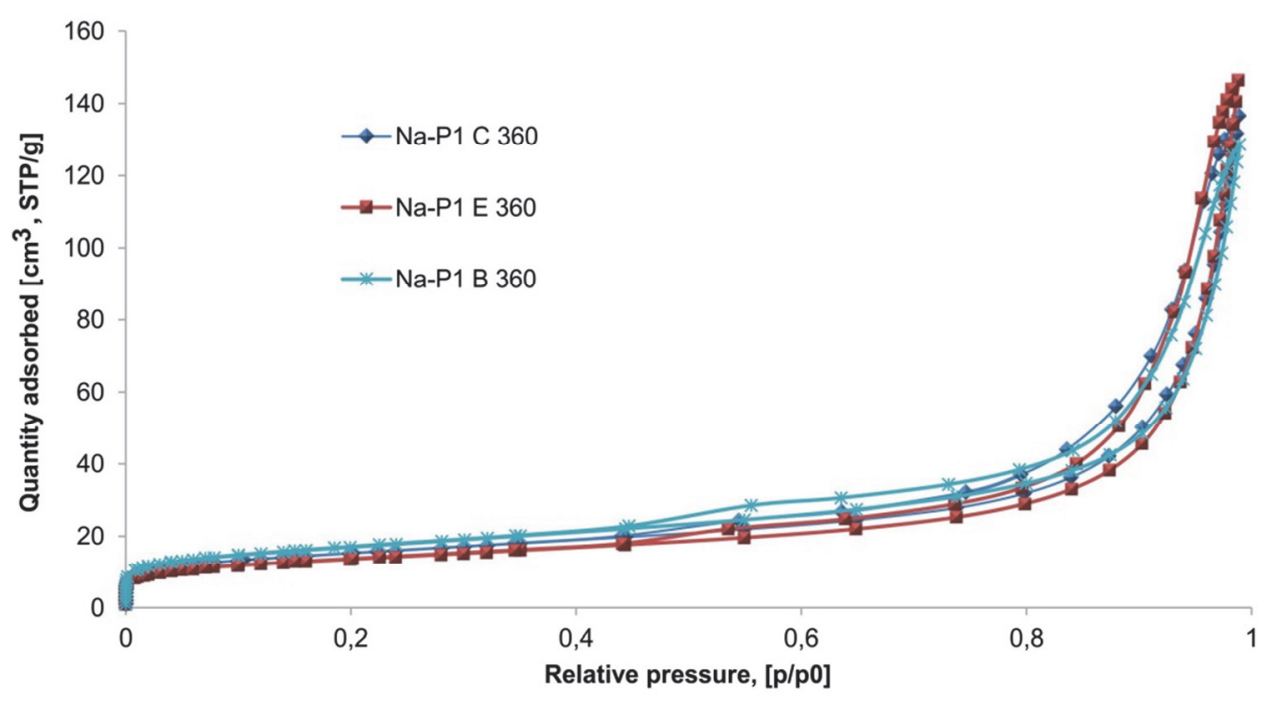

Fig. 10. The adsorption/desorption isotherms of samples prepared by the three discussed methods of compaction after seasoning for 360 days

TABLE 7

Textural parameters of Na-P1 zeolite compacted by the three tested techniques after 360 days

\begin{tabular}{llll}
\hline Parameter & Na-P1 C360 & Na-P1 B360 & Na-P1 E360 \\
\hline $\mathrm{S}_{\mathrm{BET}}\left[\mathrm{m}^{2} \cdot \mathrm{g}^{-1}\right]$ & 52.221 & 57.872 & 46.801 \\
$\mathrm{~S}_{\text {mic. } .}\left[\mathrm{m}^{2} \cdot \mathrm{g}^{-1}\right]$ & 15.113 & 15.161 & 13.243 \\
$\mathrm{~S}_{\text {mes. } . \mathrm{m}}\left[\mathrm{m}^{2} \cdot \mathrm{g}^{-1}\right]$ & 40.610 & 49.980 & 36.891 \\
$\mathrm{~V}_{\text {mic.t }}\left[\mathrm{cm}^{3} \cdot \mathrm{g}^{-1}\right]$ & 0.006 & 0.005 & 0.005 \\
$\mathrm{~V}_{\text {mes.t }}\left[\mathrm{cm}^{3} \cdot \mathrm{g}^{-1}\right]$ & 0.205 & 0.194 & 0.222 \\
$\mathrm{~V}_{\text {tot }}\left[\mathrm{cm}^{3} \cdot \mathrm{g}^{-1}\right]$ & 0.211 & 0.199 & 0.227 \\
$\mathrm{D}_{\text {mes }}[\mathrm{nm}]$ & 20.233 & 16.481 & 24.031 \\
$\mathrm{D}_{\text {med }}[\mathrm{nm}]$ & 15.224 & 12.811 & 18.091 \\
\hline
\end{tabular}

By comparing the data in Table 7 it is clear that the zeolitic material, obtained from Class F fly ash containing desulphurization products, compacted with cement has an unstable texture in time, independently of the conditions of the preparation of the compacted forms (i.e. compaction technique and moisture content). The specific surface area decreases by approximately $20 \%$ for the tablets with cement binder, and by approximately $40 \%$ for the briquettes with the same binder. The same tendency is seen in the case of the values of the mesopores' surface area. However, after one year the surface area of the micropores increases for the tablets, while it decreases for the two other tested samples, which can increase $\mathrm{CO}_{2}$ sorption (tests are under investigation) (Panek et al. 2016). To conclude, it is possible to control to a limited extent the values of the texture 
parameters by selecting the method of compaction and seasoning condition (Gara et al. 2008).

\section{Conclusion}

Na-P1 zeolite is not thermally stable, and therefore to obtain a compacted form it requires a binder other than those commonly used (kaolinite and bentonite), as well as the specific techniques of compaction.

From among the three tested binders (molasses, water glass and cement), only cement provided adequate mechanical strength and resistance to water of the obtained granular zeolites forms.

The use of a granulation process (compaction and crushing to an appropriate fraction) of the Na-P1 zeolite material for the three compaction techniques of briquetting, extrusion, and tableting (with the same percentage of cement used as the binder) resulted in the formation of compacted forms with different textures. This is a result of both the differences in the applied pressure during the compaction process, and the amount of water added. This was particularly observed in the briquetting of material where green compacts were seasoned over $48 \mathrm{~h}$, showing the formation of the secondary texture as a result of the reaction of the cement components with the fly ash residues.

Zeolite material obtained from Class F fly ash containing desulphurization products and compacted using cement as a binder has an unstable texture over time. It is dependent on the method used for the preparation of the compacted forms, including not only the technique, but also the amount of water added.

By comparing the changes in values of the textural parameters for the tableted and briquetted forms of the Na-P1 zeolite material with a cement binder, it may be concluded that these parameters are established at a similar level after one year, and that they are marginally higher for the briquetted form. This is associated with the different amounts and methods of adding water to achieve the required mechanical strength, resulting at different times in the formation of the new binding phases in the cement.

It is worth mentioning that seasoning of the tableted zeolite with cement over a longer period of time increased the micropores surface, which can increase sorption of $\mathrm{CO}_{2}$.

The decrease in the value over time of the specific surface area and the surface of micro- and mesopores was followed by an increase in the average radius of the mesopores and the average radius of the total pores.

Based on the obtained results, both the impact of the type of binder as well as the method of compaction on the textural properties of the resulting granulates were established.

Acknowledgements. This work was funded by the Nation Centre Research and Development under Programme GEKON2/02/266818/1/20157.

\section{References}

Atkins, M., Glasser, F. P., \& Jack J. J. (1995). Zeolite P in cements: Its potential for immobilizing toxic and radioactive waste species. Waste Management, 15 (2), 127-135. DOI: 10.1016/0956-053X(95)00015-R. 
Bandura, L., Franus, M., Józefaciuk, G., \& Franus, W. (2015). Synthetic zeolites from fly ash as effective mineral sorbents for land-based petroleum spills cleanup. Fuel, 147, 100-107. DOI: 10.1016/j.fuel.2015.01.067.

Bieganowski, A., Łagód, G., Ryżak, M., Montusiewicz, A., Chomczyńska, M., \& Sochan, A. (2012). Measurement of activated sludge particle diameters using laser diffraction method. Ecological Chemistry and Engineering S, 19 (4), 597-608. DOI: 10.2478/v10216-011-0042-7.

Bowman, R. S. (2003). Applications of surfactant-modified zeolites to environmental remediation. Microporous and Mesoporous Materials, 61, 43-56. DOI: 10.1016/S1387-1811(03)00354-8.

Chałupnik, S., Franus, W., Wysocka, M., \& Gzyl, G. (2013). Application of zeolites for radium removal from mine water. Environmental Science and Pollution Research, 20, 7900-7906. DOI: 10.1007/s11356-013-18775 .

Charkhi, A., Kazemeini, M., Ahmadi, S. J., \& Kazemian, H. (2012). Fabrication of granulated NaY zeolite nanoparticles using a new method and study the adsorption properties. Powder Technology , 231, 1-6. DOI: 10.1016/j.powtec.2012.06.041.

Czurda, K. A., \& Haus, R. (2002). Reactive barriers with fly ash zeolites for in situ groundwater remediation. Applied Clay Science, 21, 13-20. DOI: 10.1016/S0169-1317(01)00088-6.

De la Varga, I., Castro, J., Bentz, D., \& Weiss, J. (2012). Application of internal curing for mixtures containing high volumes of fly ash. Cement and Concrete Composites, 34 (9), 1001-1008. DOI: 10.1016/j.cemconcomp.2012.06.008.

Ejsymont, J., Łaptaś, A., \& Steciu, Z. (1975). PL80674. Sposób zabezpieczenia zeolitów przed zmianami własności w procesie formowania, Patent - PL80674, 1975. [in Polish]

Ejsymont, J., \& Witek, E. (1986). Sposób granulowania zeolitów syntetycznych, Patent - PL131352, 1986. [in Polish]

Ejsymont, J., Witek, E., \& Łaptaś, A. (1981). PL103530. Sposób otrzymywania kształtek zeolitów syntetycznych, Patent - PL 103530, 1981. [in Polish]

Franus, W. (2012). Characterization of X-type zeolite prepared from coal fly ash. Polish Journal of Environmental Studies, 21 (2), 337-343

Franus, W., \& Wdowin, M. (2010). Removal of ammonium ions by selected natural and synthetic zeolites. Mineral Resource Management, 26, 133-148.

Franus, W., Wdowin, M., \& Franus, M. (2014). Synthesis and characterization of zeolites prepared from industrial fly ash. Environmental Monitoring and Assessment, 186, 5721-5729. DOI: 10.1007/s10661-014-3815-5.

Gara, P., Hryniewicz, M., \& Wisła-Walsh, E. (2008). New high surface area calcareous sorbent produced in mechanical operations. Polish Journal of Environmental Studies, 17 (3A), 198-202.

Jagielska, E. M., Berak, J., Bazarnik, A., Kazimierczuk, R., \& Apczyńsk, J. (1988). PL140558. Sposób formowania zeolitów, Patent - PL140558, 1988. [in Polish]

Kim, K-J, \& Ahn, H-G. (2012). The effect of pore structure of zeolite on the adsorption of VOCs and their desorption properties by microwave heating. Microporous and Mesoporous Materials, 152, 78-83. DOI: 10.1016/j.micromeso.2011.11.051.

Klinik, J. (2000). Tekstura porowatych ciał stałych. Kraków: Ośrodek Edukacji Niestacjonarnej Akademia Górniczo-Hutnicza. [in Polish]

Knight, P. C. (2001). Structuring agglomerated products for improved performance. Powder Technology, 119 (1), 14-25. DOI: 10.1016/S0032-5910(01)00400-4.

Kurdowski, W. (2010). Chemia cementu i betonu, Warszawa: Wydawnictwo naukowe PWN. [in Polish]

Lipkind, B. A., Valuiskaya, O. M., Kanakova, O. A., Nefedov, B. K. (1987). Forming of synthetic zeolites with binder additives into microbead granules. Chemistry and Technology of Fuels and Oils, 23(10), 476-478. DOI: $10.1007 / \mathrm{BF} 00724830$

Lippens, B. C., \& de Boer, J. H. (1965). Studies on pore systems in catalysts. V. The t method. Journal of Catalysis, 4, 319-323. DOI: 10.1016/0021-9517(65)90307-6.

Lippens, B. C., Linsen, B. G., \& de Boer, J. H. (1964). Studies on pore systems in catalysts I. The adsorption of nitrogen; apparatus and calculation. Journal of Catalysis, 3, 32-37. DOI: 10.1016/0021-9517(64)90089-2.

Majchrzak-Kucęba, I. (2011). Mikroporowate i mezoporowate materiały z popiołów lotnych. Monografie Politechniki Częstochowskiej, 201, (pp. 1-208). Częstochowa : Wydaw. Politechniki Częstochowskiej. [in Polish]

Manikandan, R., \& Ramamurthy, K. (2007). Influence of fineness of fly ash on the aggregate pelletization process. Cement and Concrete Composites, 29(6), 456-464. DOI: 10.1016/j.cemconcomp.2007.01.002. 
Matsi, T., \& Keramidas, V. Z. (1999). Fly ash application on two acid soils and its effect on soil salinity, pH, B, P and on ryegrass growth and composition. Environmental Pollution, 104, 107-112. DOI: 10.1016/S02697491(98)00145-6.

Mehra, A., Farago, M. E., \& Banerjee, D. K. (1998). Impact of fly ash from coal-fired power stations in Delhi, with particular reference to metal contamination. Environmental Monitoring and Assessment, 50(1), 15-35. DOI: $10.1023 / \mathrm{A}: 1005860015123$

Merrikhpour, H., \& Jalali, M. (2012). Comparative and competitive adsorption of cadmium,copper, nickel, and lead ions by Iranian natural zeolite. Clean Technologies and Environmental Policy, 15, 303-316. DOI: 10.1007/s10098-012-0522-1.

Misaelides, P. (2011). Application of natural zeolites in environmental remediation: a short review. Microporous and Mesoporous Materials, 144, 15-18. DOI: 10.1016/j.micromeso.2011.03.024.

Morency, J. R., Panagiotou, T., \& Senior, C. L. (2002). Zeolite sorbent that effectively removes mercury from flue gases. Filtration \& Separation, 39(7), 24-26. DOI: 10.1016/S0015-1882(02)80207-5.

Northcott, K. A., Bacus, J., Taya, N., Komatsu, Y., Perera, J. M., \& Stevens, G. W. (2010). Synthesis and characterization of hydrophobic zeolite for the treatment of hydrocarbon contaminated ground water. Journal of Hazardous Materials183, 434-40. DOI: 10.1016/j.jhazmat.2010.07.043.

Panek, R., Wisła-Walsh, E., Gara, P., \& Wdowin, M. (2016).The zeolite-carbon composite as $\mathrm{CO}_{2}$ sorbent. Proceedings - 18th International Zeolite Conference - Zeolites for a Sustainable World, 19 June - 24 June 2016. Rio de Janeiro, Brazil.

Perego, C., Bagatin, R., Tagliabue, M., \& Vignola, R. (2013). Zeolites and related mesoporous materials for multitalented environmental solutions. Microporous and Mesoporous Materials, 166, 37-49. DOI: 10.1016/j.micromeso.2012.04.048

Pietsch, W. (2004). Agglomeration in Industry: Occurence and Applications (1 Ed). Weinheim: Wiley-VCH.

Remenárová, L., Pipíška, M., Florková, E., Augustín, J., Rozložník, M., Hostin, S., \& Horník M. (2014). Radiocesium adsorption by zeolitic materials synthesized from coal fly ash. Nova Biotechnologica et Chimica, 13(1), 57-72. DOI: 10.2478/nbec-2014-0007.

Sarbak, Z. (2002). Surface centres for CO adsorption on supported platinum. Adsorption Science \& Technology, 20, 347-351. DOI: abs/10.1260/02636170260295533.

Scrivener, K. L., \& Nonat, A. (2011). Hydration of cementitious materials, present and future. Cement and Concrete Research41(7), 651-665. DOI: 10.1016/j.cemconres.2011.03.026.

Simpson, J. A., \& Bowman, R. S. (2009). Nonequilibrium sorption and transport of volatile petroleum hydrocarbons in surfactant-modified zeolite. Journal of Contaminant Hydrology, 108, 1-11. DOI: 10.1016/j.jconhyd.2009.05.001.

Singh, N. B., Rai, S., \& Chaturvedi, S. (2002). Hydration of Composite Cement. Progress in Crystal Growth and Characterization of Materials, 45, 171-174. DOI: 10.1016/S0960-8974(02)00045-1.

Sochon, R. P. J., \& Salman, A. D. (2010). Particle growth and agglomeration processes. In R. Pohorecki (Eds.), Chemical Engineering and chemical process technology (vol.2) (pp.299-317). Singapore: Eolss Publishers Co. UK.

Srb J., \& Ruzickova Z. (1988). Pelletization of Fines (Minerals, Ores, Coal) In D.W. Fuerstenau, Advisory Editor, Developments in Mineral Processing Vol 7 (pp. 292-296). Elsevier Science Publishers B.V., Amsterdam, The Netherlands

Sumer, M. (2012). Compressive strength and sulfate resistance properties of concretes containing Class F and Class C fly ashes. Construction and Building Materials, 34, 531-536. DOI 10.1016/j.conbuildmat.2012.02.023.

Swanepoel, J. C., \& Strydom, C. A. (2002). Utilisation of fly ash in a geopolymeric material. Applied Geochemistry17, 1143-1148. DOI: 10.1016/S0883-2927(02)00005-7.

Szala, B., Bajda, T., Matusik, J., Zięba, K., \& Kijak, B. (2015). BTX sorption on Na-P1 organozeolite as a process controlled by the amount of adsorbed HDTMA. Microporous and Mesoporous Materials, 202, 115-123. DOI 10.1016/j.micromeso.2014.09.033.

Tharnzil L. (1997). Immobilization of $137 \mathrm{Cs}$ on cement-zeolite composites. Waste Treatment and Immobilization Technologies Involving Inorganic Sorbents. Final report IAEA-TECDOC-947. Vienna, Austria: International Atomic Energy Agency, Vienna, 153-162.

Ugal, J. R., Mustafa, M., \& Abdulhadi, A. A. (2008). Preparation of zeolite type 13x from locally available raw materials. Iraqi Journal of Chemical and Petroleum Engineering, 9(1), 51-56. 
Vignola, R., Bagatin, R., De Folly D’Auris, A., Flego, C., Nalli, M., Ghisletti, D. (2011). Zeolites in a permeable reactive barrier (PRB): one year of field experience in a refinery groundwater-Part 1: The performances. Chemical Engineering Journal178, 204-209. DOI: 10.1016/j.cej.2011.10.050.

Wajszel, D. (1982). PL113134. Sposób formowania granule zeolitowych zwłaszcza o wymiarze ziaren 0,6 - 1,0 mm, Patent - PL113134 1982. [in Polish]

Wdowin, M., Franus, M., Panek, R., Bandura, L., \& Franus, W. (2014). The conversion technology of fly ash into zeolites. Clean Technologies and Environmental Policy, 16, 1217-1223. DOI: 10.1007/s10098-014-0719-6.

Wdowin, M., Franus, W., \& Panek, R. (2012). Preliminary results of usage possibilities of carbonate and zeolitic sorbents in $\mathrm{CO}_{2}$ capture. Fresenius Environmental Bulletin, 21(12), 3726-3734

Wdowin, M., Wiatros-Motyka, M., Panek, R., Stevens, Lee A., Wojciech, F., \& Snape, C. E. (2014). Experimental study of mercury removal from exhaust gases. Fuel, 128, 451-457. DOI: 10.1016/j.fuel.2014.03.041.

Wdowin, W., Macherzyński, M., Panek, R., Górecki, J., \& Franus, W. (2015). Investigation of the mercury vapour sorption from exhaust gas by an Ag-X zeolite. Clay Minerals, 50(1), 31-40. DOI: 10.1180/claymin.2015.050.1.04

Wisła-Walsh, E., Mięso, R., \& Sikora, W.S. (1999). Research into fly ash agglomeration process and physicochemical properties of pellets. Mineralogia Special Papers, 13, (pp.100-120). Kraków: Mineralogical Society of Poland.

Yang, R., Liao, W-P., \& Wu, P-H. (2012). Basic characteristics of leachate produced by various washing processes for MSWI ashes in Taiwan. Journal of Environmental Management 104, 67-76. DOI: 10.1016/j.jenvman.2012.03.008.

Yoo, J. G., \& Jo, Y. M. (2003). Finding the optimum binder for fly ash pelletization. Fuel Processing Technology 81(3), 173-186. DOI: 10.1016/S0378-3820(03)00011-0.

Zhang, M., Zhang, H., Xu, D., Han, L., Niu, D., \& Tian, B. (2011). Removal of ammonium from aqueous solutions using zeolite synthesized from fly ash by a fusion method. Desalination, 271, 111-121. DOI: 10.1016/j.desal.2010.12.021. 